\title{
MONITORING ARTISANAL HILSA FISHERY FOR ECONOMIC EFFICIENT FISHERIES POLICY
}

\author{
Masud Ara Mome* and Ragnar Arnason ${ }^{1}$ \\ Department of Fisheries, Matshya Bhaban, Dhaka, Bangladesh.
}

\begin{abstract}
The hilsa shad (Tenualosa ilisha) fishery contributes to the largest single species fishery in Bangladesh. In this paper, a simple bio-economic year-class based model was developed from $1987 \& 2007$ fishing data to describe the fishery and examine its properties. With the help of this model, the optimum sustainable yield of the fishery was calculated and compared to the existing situation. The model was

further used to locate socially and economically reasonable dynamic paths from the current situation to the optimal state. The results indicate that the fishing effort (measured in standardized boat units) required maintaining a maximum sustainable economic benefit is about one-third of the current fishing effort. At this sustainable fishing effort level, annual net economic benefits from the fishery amounted for closed to US\$ 260 million compared to virtually nothing at present. The present value of the fishery along a moderate effort adjustment path to this long term equilibrium position was US\$ 3,650 million at $6 \%$ rate of discount. The dynamic path that maximized the present value of the fishery involved quite dramatic effort reductions for the first two years. Such a path would probably increase the present value of the fishery by perhaps $8-10 \%$.
\end{abstract}

Key words: Bio-economic model, optimum sustainable yield, fishing effort, dynamic adjustment paths.

\section{INTRODUCTION}

Bangladesh is a major fishing nation with annual catches exceeding 2 million metric tonnes $(\mathrm{mt})$ in recent years. The country's total fish production has nearly doubled since 1996 reaching 2.2 million $\mathrm{mt}$ in 2007.These catches came from both marine and fresh water resources. Fisheries play quite an important role in Bangladesh in terms of protein supply, employment generation and foreign currency earnings. The fisheries sector contributes about $4 \%$ to the GDP and $22 \%$ to the total value of agricultural production (DoF 2007). Almost 5\% of the country's export earning comes from this sector. Fish provides about $60 \%$ of animal protein intake of the population (DoF, 2007). The fisheries sector provides full time employment to about 1.3 million fishers and part time employment to about 12 million fisher folk, which is about $10 \%$ of the total population (DoF 2005). In the year 2005-06, about $11 \%$ of the country's total fish production (by volume) came from hilsa. Average hilsa production has in recent years been about 215 thousand $\mathrm{mt}$ with landed value about 380 million US\$. The most part of the hilsa fishery is conducted by small scale, low

* Corresponding author: E-mail: masudara_momi@yahoo.co.uk.

${ }^{1}$ Professor, University of Iceland. Iceland. 
technology artisanal fishermen numbering in excess of 420 thousand (Halder 2004). The hilsa fishery contributes about $1 \%$ to the total fisheries sector GDP in Bangladesh (DoF 2010).

The hilsa fishery of Bangladesh is characterized by the common property (or common pool) arrangement with the available resources being accessible to a large number of actual and potential fishers. There was an increase in the number of fishers and fishing effort (Gordon 1954 and Hardin 1968), while an economic surplus was obtainable. In certain upstream areas where the harvesting of hilsa is particularly easy, this process has worked itself out fully and has now entered a contractive phase because of lack of fish. Since alternative sources of subsistence are usually not readily available, the social consequences have been quite severe. Due to the depletion of fish in upstream areas, hilsa fishing has moved to downstream and especially to inshore marine waters where sufficient concentrations of hilsa are now found. In these areas hilsa fishing requires more fishing capital and is more expensive. Adequate limitations, controls on fishing vessels and fishing effort have not been in place to counter the expansion in this sector of the fishery (Halder 2004). In addition to overexploitation of the hilsa stocks, fishing vessel crowding on the best fishing grounds has been a problem.

In spite of its economic importance, we are not able to find any systematic studies of the economics of the hilsa fishery. To maintain and enhance the hilsa stock, many biologically-based management measure have been introduced. It is now well established that these kinds of fisheries management measures are not capable of generating the maximum flow of net economic benefits flowing from the stock (Arnason 1984).

The aim of this research is to develop a bio-economic model for the hilsa fishery which can be used as a first step towards improved management of this fishery. On the basis of this model, the optimal sustainable yield will be calculated comparing to the existing situation In addition, the model will be used to locate socially and economically reasonable paths from the current state of the fishery to the long run optimal fishing approach. Measures of the social gains from doing this will be calculated.

\section{MATERIAL AND METHODS}

Data sources of Hilsa fishery: The hilsa fishery is described by the avaiable data from the Department of Fisheries statistical division from 1987 to 2007. For estimating the current model secondary and tertiary data will be utilised. The secondary data has been collected from the Fisheries Resources Survey System (FRSS) and Fish Inspection and Quality Control (FIQC) section in Bangladesh and tertiary data from different websites and from various working reports. FRSS is an important section of the Department of Fisheries under the administrative control of the Ministry of Fisheries and Livestock. All biological 
data for this study were collected from "Aquatic Resource Management, Development and Conservation Studies" (ARDMCS), GEF component of the Fourth Fisheries Project (FFP) under the administration of the DoF (Halder 2004b).

Status of Hilsa Fishery: Tenualosa ilisha or hilsa belongs to the Family Clupeidae is anadromous in nature and occurs in marine, estuarine and river environments. The hilsa has a wide geographical distribution in Asia from the Persian Gulf to the South China Sea. Particularly large stocks are found in Upper Bay of Bengal region sustained by the large river systems. In Bangladesh hilsa may reach up to $60 \mathrm{~cm}$ in total length and $3 \mathrm{~kg}$. in weight at four years of age. Most commonly found hilsa is 35 to $40 \mathrm{~cm}$. and less than $1 \mathrm{~kg}$. Mature hilsa migrate upstream primarily during the southwest monsoon and consequent flooding of the rivers (Rahman, 2005). The larvae and juveniles make their way downstream to the sea during a period of 5-6 months feeding and growing on the way. At an age of about six to ten weeks the fry have grown to about $12-20 \mathrm{~cm}$. (0.1 kg in weight). At this size they are known as 'jatka' and subject to heavy fishing mortality. Maturity occurs between 6 and 12 months of age where the survivors undertake their first spawning migration upriver (Haroon 1998). In Bangladesh there are about $2 \%$ of the country's total population depending for their livelihood on the hilsa fishery (hilsa and jatka catching) directly or indirectly (Halder 2002). During the last two decades the hilsa catch has ranged between 195 to 280 thousand mt. per year with an average of 218 thousand $\mathrm{mt}$. Over this period there has been a clear upward trend in total catch rates while inland hilsa catches have declined (Fig. 1). These trends probably reflect increased fishing pressure partly propelled by improved technology of fishing (nylon twine and motorized vessels) as well as declining stocks (Raja 1985 and Hall and Kasem 1994).

Most hilsa fishing in Bangladesh is conducted by small scale, low technology, labour intensive fishing methods which may be classified as predominantly an artisanal fishery. The hilsa stocks are exploited by a variety of gears, the most common of which are clap nets, gillnets, driftnets, seine nets, barrier nets, and fixed bag nets. The largest part of the harvest, however, is caught by gillnets. These gillnets are set with the help of small (usually under $10 \mathrm{~m}$.) non-motorized and motorized fishing vessels boats. Motorized fishing vessels employing gillnets now account for the bulk of the landings from the sea. Hilsa is marketed and consumed all over Bangladesh. According to Kleih et al. 2003, 88\% of hilsa is marketed for domestic consumption while the remaining $12 \%$ is exported. 


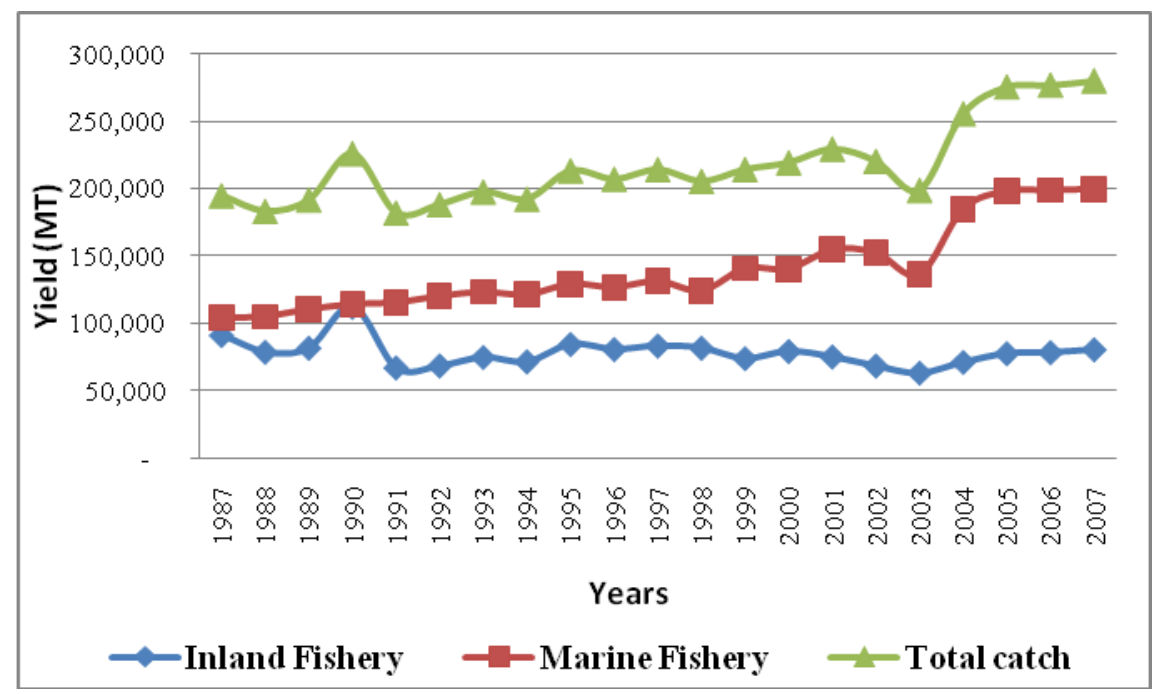

Fig. 1. Trends of hilsa harvest (both inland and marine sector) in Bangladesh during 1987 to 2007

In 1984-1985 the total number of non-motorized hilsa fishing vessels was 3802. In 2005-2006 this number has risen to 6377. The corresponding increase in the number of motorized boats shows an even more dramatic increase of fisheries effort. In 1984-1985 this number was 2887 and in 2005-2006 the number had risen to 18992 (DoF 2007). At the same time the fishing gear technology has improved greatly (e.g. nylon twine) substantially increasing the fishing power of each fishing boat. As expected this increase in fishing fleet and, therefore, effort has lead to a drastic reduction in catch per unit of vessel. This holds in particular for the motorized fleet whose catch per boat has fallen by $2 / 3$ since 1986.

The evolution of catch per unit effort (in terms mechanized boats) is illustrated in Fig. 2. For the motorized boats, the official statistics during the period 1987 to 1999 are extremely unreliable. Therefore, in Figure 2, they are replaced by estimates based on the exponential function.

Modelling: The bioeconomic model employed in this study is a cohort disaggregated dynamic one. It consists of a biological part, a harvesting part and a profit function. The biological part describes the evolution of the stock over time. The profit function describes the economic benefits from fishing. The harvesting part relates control variables of the model, i.e. the variables subject to fisheries management, to fishing mortality and thus constitutes the link between the economic and biological part of the model. The control variables of the model are fishing effort and protection of young cohorts. 


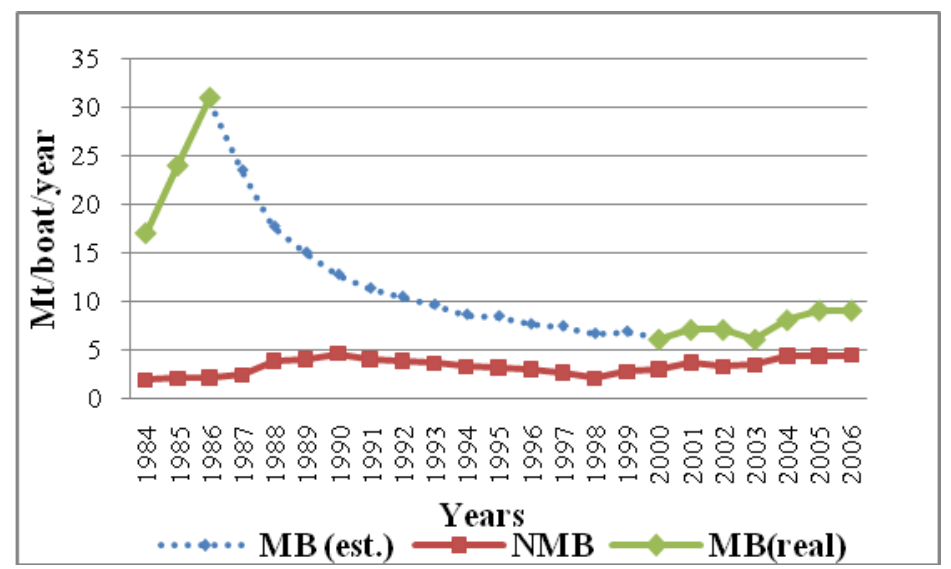

Fig. 2. Catch per unit efforts of mechanized and non mechanized boats

Biological part of the model

The biological part the model is based on the theoretical framework set out by Beverton and Holt in 1957. The key functional relationships of the BevertonHolt model are:

$$
n(i, t+1)=n(i, t) \cdot e^{-z(i, t)} \mathrm{w}
$$

where $n(i, t)$ denotes the number of fish in cohort $i$ at time $t$ and $z(i, t)=m(i, t)+f(i, t)$ where $m(i, t)$ and $f(i, t)$ represent natural and fishing mortality rates respectively.

Cohort biomass is:

$$
x(i, t)=\mathrm{w}(i, t) \cdot n(i, t)
$$

where $w(i, t)$; average weight of fish in cohort $i$ at time $t$.

Total biomass is:

$$
X(t)=\sum_{i=1}^{I} x(i, t)
$$

where $I$ is the maximum number of cohorts in the stock.

Spawning stock is:

$$
S(t)=\sum_{i=1}^{I} m a(i, t) \cdot x(i, t)
$$

where $m a(i, t)$ is the average maturity of fish in cohort $i$ at time $t$.

Relationships between (1) to (4) are all logical necessities or tautologies. The following Beverton-Holt recruitment function (Beverton and Holt 1957) is an empirical hypothesis:

$$
r(t)=\frac{\alpha \cdot S(t-\sigma)}{1+\beta \cdot S(t-\sigma)}
$$


where $a$ and $\beta$ are coefficients and $\sigma \geq 0$ is the lead time from the time of spawning to the time of recruitment. The Beverton-Holt recruitment function is a monotonically increasing function with an asymptotic maximum at $\alpha / \beta$. Typical shapes of this function for different values of $\alpha$ but the same maximum recruitment are illustrated in Fig. 3.

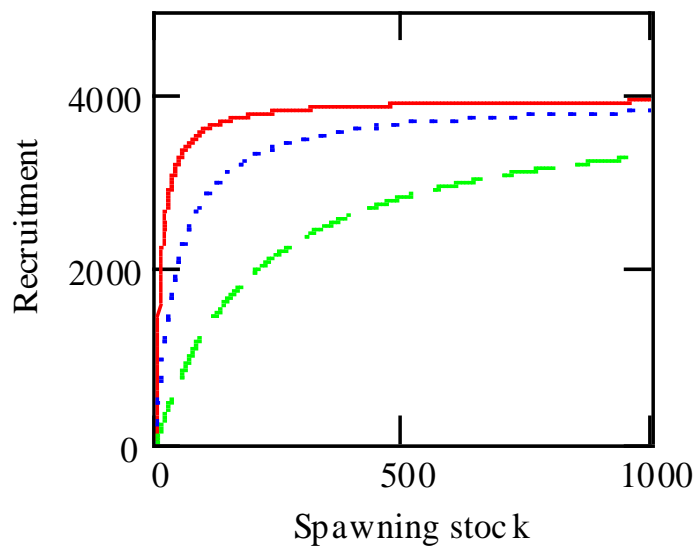

Fig. 3. Examples of Beverton-Holt recruitment functions

\section{Economical part of the model}

Aggregate costs of fishing effort at time $t$ are given by the function:

$$
C(e f(t))=f k+v c \cdot e f(t)
$$

In this function, $f k$ is the fixed cost and $v c$ is the variable cost per unit effort denoted by $e f(t)$. For long run calculation we assume that $f k$ becomes variable so the long run cost function would be:

$$
C(e f)=(f k+v c) \cdot e f
$$

This is equivalent to assuming that adjusting aggregate fishing effort amounts to altering the number of active fishing boats in the fishery. The implication is that long run aggregate fishing costs vary proportionately with aggregate fishing effort.

Aggregate profits at time $t$ are;

$$
\pi(t)=p(t) \cdot y(t)-C(e f(t))
$$

where $p(t)$ is the price of landings and $y(t)$ the harvest both at time $t$. In empirical implementations of the model price may vary across cohorts.

The present value of profits from the fishery over some arbitrary period of time $T+1$ are defined by the expression: 


$$
P V=\frac{\sum_{t=0}^{T} \pi(t)}{(1+r)^{t}}
$$

where $r$ is the rate of discount.

The link between the biological and economic parts of the model

The link between the biological and economic parts of the model is given by the harvesting function. As deduced by Beverton and Holt in 1957, the harvesting function for a single cohort $i$ over time period $[t, t+1]$ is given by:

$$
y(i, t)=w(i, t) \cdot n(i, t) \cdot\left(1-e^{-z(i, t)}\right) \cdot \frac{f(i, t)}{z(i, t)}
$$

where $w(i, t), m(i, t)$ and $f(i, t)$ are averages over the fishing period.

The total harvest then is just the summation over all the cohorts as-

$$
Y(t)=\sum_{i=1}^{I} y(i, t)
$$

Fishing mortality depends on fishing effort and special measures to protect young cohorts. Following Arnason (1984), we assume that fishing mortality for year class $i$ at time $t$ is a linear function of fishing effort. In the base year, $t^{\star}$, we have a column in vector of fishing mortality, $F=\left[f\left(1, t^{*}\right), f\left(2, t^{*}\right), \ldots, \mathrm{f}\left(I, t^{*}\right)\right]$.

Therefore, fishing mortality for any cohort at any time $t$ is:

$$
f(i, t)=f\left(i, t^{*}\right) \cdot\left(\frac{e(t)}{e\left(t^{*}\right)}\right) \cdot \operatorname{pr}(i, t)
$$

where $\operatorname{pr}(i, t) \in[0,1]$ represents protection for cohort $i$ at time $t . \operatorname{pr}(i, t)=0$ means full protection and $\operatorname{pr}(i, t)=0$ means no special protection.

\section{Data and Parameter Estimations}

In order to apply the model outlined above, it is necessary to obtain estimates its parameters. More precisely, we need estimates of the following parameters:

Table 1. Necessary parameters to estimate the population features

\begin{tabular}{lclc}
\hline Biological features & $\begin{array}{c}\text { Names of the } \\
\text { parameters }\end{array}$ & Economic features & $\begin{array}{c}\text { Names of the } \\
\text { parameters }\end{array}$ \\
\hline Life span & $I$ & $\begin{array}{l}\text { Fishing effort in } \\
\text { base year }\end{array}$ & ef* \\
Maturity rates & $m a(i, t)$, all $i$ & Fixed costs & $f k$ \\
Numbers of fish in base year & $N\left(i, t^{*}\right)$, all $i$ & Variable costs & $v c$ \\
Average individual weights & $w(i, t)$, all $i$ & Landings price & $p$
\end{tabular}




$\begin{array}{lc}\text { Natural mortality } & m(i, t), \text { all } i \\ \text { Fishing mortality in base year } & f\left(i, t^{*}\right) \text {, all } i \\ \begin{array}{l}\text { Recruitment function } \\ \text { parameters }\end{array} & a, \beta, \sigma\end{array}$

In addition to this we obviously need to decide on the time interval to use and the base year of the calculations, $t^{*}$.

Time unit and the base year: We select to use half-years as our basic time unit. This is because the hilsa grow fast and natural mortality is high. Therefore, increased accuracy is gained by using half years in the calculations rather than whole years. The year 2005 is taken to be the base year for this study.

\section{Biological data and parameters}

Life Span: According to Halder (2004), hilsa attain its maximum length 58 $\mathrm{cm}$, at 6.5 years of age. However, if only due to a high natural mortality rate, very few fish older than four years are left in the stock. Therefore, in our calculations we consider hilsa life span up to 4 years of age which corresponds to eight half year cohorts.

Maturity Rates: The minimum size of mature hilsa is reported to be $19 \mathrm{~cm}$ (Halder, 2002). This length is reached at about 7-8th month of the hilsa's life. On this basis, it is assumed that the youngest cohort of hilsa $(0$ to 0.5 years in age) is immature and the second cohort ( 0.5 to 1 year of age) is $80 \%$ mature. The remaining cohorts are fully mature.

Numbers of fish in base year: Up-to-date estimates of cohort sizes for hilsa in Bangladesh are not available. There are estimates, however, of the total stock size, natural and fishing mortality and on that basis some indirect evidence of the recruitment functions. With the help of these data we have constructed a vector of cohort sizes in the base year as listed in Table 2. These numbers are reasonable in the sense that they reproduce approximately the stock sizes as estimated and, combined with fishing and natural mortality, the observed catches in the base year.

Average individual weight: As for the other tropical fish, ageing of hilsa is problematic, because of the absence of annual rings on scales. To partly solve this problem microstructure examination of year marks/daily rings were in otoliths of the species was conducted with limited success in Bangladesh waters (Quddus et al. 1984). On the other hand, a great deal of evidence is available about the hilsa growth process. Haldar, 2004 determines the hilsa's length by age. We use that published data (length by age) in this study. With that in hand, we use Le Cren's (1951) equation to calculate weight by length (and therefore also age) according to:

$$
W=0.01351 l^{2.974}
$$


Natural mortality: Several researches have done for natural and total mortality of hilsa. Amin et al. (2000) have published estimates of the total and natural mortality of hilsa. According to this study, the mortality rates for the stock as a whole are very high, especially for the first (half year) cohort. Moreover, Miah and Shafi, 1995, Rahman et al., 1998 and Rahman et al., 2000, estimates the similar result of mortality rates for the same species. On this basis, we have adopted natural mortality estimates as listed in Table 2

Fishing mortality in base year: Fishing mortality in the base year rate, $f(i, t)$, was obtained by subtracting $m(i, t)$ from $z(i, t)$. The results are listed in Table 2

Table 2. Basic biological data and parameters for this study

\begin{tabular}{ccccccc}
\hline $\begin{array}{c}\text { Age } \\
\text { (year) }\end{array}$ & $\begin{array}{c}\text { Base year } \\
\text { cohort nos. } \\
\text { (million fish) }\end{array}$ & $\begin{array}{c}\text { Individual } \\
\text { weight (kg) }\end{array}$ & $\begin{array}{c}\text { Biomass } \\
(1000 \mathrm{mt})\end{array}$ & $\begin{array}{c}\text { Natural } \\
\text { mortality }\end{array}$ & $\begin{array}{c}\text { Fishing } \\
\text { mortality }\end{array}$ & $\begin{array}{c}\text { Maturity } \\
\text { rate }\end{array}$ \\
\hline 0.5 & 24928.0 & 0.051 & 1271.3 & 4.00 & 10.50 & 0 \\
1.0 & 456.6 & 0.272 & 124.0 & 0,64 & 1.64 & 0.8 \\
1.5 & 88.6 & 0.623 & 55.2 & 0,64 & 1.64 & 1.0 \\
2.0 & 17.2 & 0.974 & 16.8 & 0,64 & 1.64 & 1.0 \\
2.5 & 3.3 & 1.351 & 4.5 & 0,64 & 1.64 & 1.0 \\
3.0 & 0.6 & 1.714 & 1.0 & 0,64 & 1.64 & 1.0 \\
3.5 & 0.1 & 1.918 & 0.2 & 0,64 & 1.64 & 1.0 \\
4.0 & 0.0 & 2.137 & 0.0 & 0,64 & 1.64 & 1.0 \\
\hline
\end{tabular}

Spawning parameters: Young hilsa, as explained above, are recruited to the fishery at a very early age. Therefore we set the recruitment lead time, $\sigma$, equal to zero. The other two spawning parameters, $a$ and $\beta$ are determined so as to replicate as closely as possible the available data of the fishery, especially harvest rates, and available estimate of stock size. This resulted in the following estimates: $a=390, \beta=0,01$.

Economic parameters estimation

Fishing effort in the base year, $e\left(t^{*}\right)$ : In this study, it was decided to measure fishing effort is estimated in horsepower (HP) units. In the base year, the total numbers of motorized and non-motorized hilsa vessels were 18,982 and 6,377 respectively. On the basis of DoF study in 2004 by interviewed with stakeholders in the fishery the HP of artisanal motorized boats ware estimated to be around 10-15 HP. On the basis of the harvesting efficiency of the non-motorized boats, it was estimated that their fishing capacity was about half of that of the motorized boats (DOF 2005-06). Therefore, measured in HP, their individual fishing effort was taken to be 5 HP. On this basis the total fishing effort in the base year was estimated to be 221,705 HP-units.

Estimates of cost parameters: We estimate fixed costs as depreciation of the capital in the boat, the interest on the capital tied up in the boat and the boat's 
maintenance costs. A new motorized boat fully equipped cost 1,000,000 Tk including sales tax and duties. On this basis fixed costs per year are calculated to be $145,000 \mathrm{Tk}$. The fixed costs of a non-motorized boat are much lower or about 60,000 Tk per year.

The variable costs consist primarily of owner's salary, crew remuneration, fishing gear and fuel. The number of crew is the same in both types of boats but crew remuneration per unit of catch is substantially less in the motorized boats. Fuel costs, on the other hand, are substantial additional expense in the motorized boats. Catch rates in motorized boats are substantially greater in motorized boats or about $9 \mathrm{mt}$. per year in motorized boats vs. $4.4 \mathrm{mt}$. for the non-motorized ones. All in all it appears variable costs (per unit of catch) are about $92.3 \mathrm{Tk} / \mathrm{kg}$ for motorized boats compared to about $97.7 \mathrm{Tk} / \mathrm{kg}$ for nonmotorized boats.

This suggests that at the catch rates reported $(9.0 \mathrm{mt}$ per year for the motorized boat vs. $4.4 \mathrm{mt}$ for the non-motorized boat) the motorized boats are about $5 \%$ more efficient than the non-motorized ones. For the former, total costs per unit of harvest are about $106 \mathrm{Tk} / \mathrm{kg}$ compared to about $111 \mathrm{Tk} / \mathrm{kg}$ for the latter.

Price of hilsa at base year, $p\left(t^{*}\right)$ : According to the FIQC survey, 2007, the landing price of hilsa is $130 \mathrm{Tk} / \mathrm{kg}$. This corresponds to $1.91 \mathrm{US} \$$ per $\mathrm{kg}$. The price of jatka (small hilsa) is much lower or about $65 \mathrm{Tk} / \mathrm{kg}$. This corresponds to 0.96 US\$ per kg. This price was used for valuing hilsa fishery.

\section{RESULTS AND DISCUSSION}

Using the hilsa bio-economic model to identify optimal fisheries policies, first we work out the optimal (profit maximizing) sustainable policy and compare it with the current state of the fishery. We then attempt to determine economically efficient adjustment paths for the fishery from its current position to the optimal sustainable one. We work out two paths of this kind. One of them simply maximizes the present value of economic return from the fishery. This path is quite dramatic in terms of shifts in fishing effort and harvests. The other path is moderate in the sense that it adjusts fishing effort and catches by relatively modest amounts each year until the optimal sustainable levels are attained.

Optimum Sustainable Yield (OSY) for hilsa fishery in Bangladesh

Applying the above model, we calculate the optimal sustainable position of the fishery. This occurs at fishing effort which is one-third (0.33) of the base year fishing effort level and total protection of hilsa under 6 months of age (i.e. jatka), i.e. $\operatorname{pr}(1, t)=0$. The corresponding sustainable (half year) yield is 94.7 thousand $\mathrm{mt}$. The (half year) sustainable yield function for this fishery and the optimal solution are illustrated in Figure 5 . Note that both this yield and the corresponding effort are somewhat less than the MSY levels. At the optimal sustainable yield level, the mature biomass of hilsa will be much higher than the 
current stock or 417 thousand $\mathrm{mt}$ compared to about 177 thousand $\mathrm{mt}$ currently.

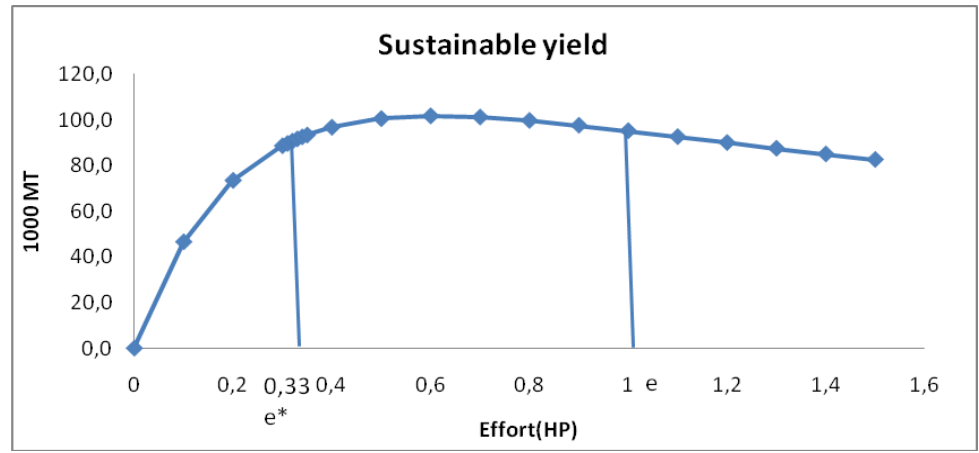

Fig. 4. Sustainable yield of hilsa fishery (per $1 / 2$ year)

The key economic aspects of the sustainable fishery are illustrated in Figure 6. In this diagram the sustainable revenue cost and revenue functions are drawn as a function of fishing effort. As indicated in the diagram the maximum sustainable profits from the hilsa fishery are about 128 million US\$ per half year. These profits are about $2 / 3$ of the total revenues indicating the potentially low costs of extracting harvest from this fishery.

At the current fishing effort level, ef=1, there would be slight sustainable profits in the fishery amounting to about US\$14 million per half year. Note, however, that this is calculated on the assumption that as in the optimal sustainable case, jatka would be protected from fishing mortality. This is also the reason why the sustainable yield function (Figure 5) is so resilient to increased fishing effort. If young hilsa (jatka) continue to be subject to the current fishing mortality (Table 2), our calculations indicate that the fishery may not be sustainable at the present fishing effort level.

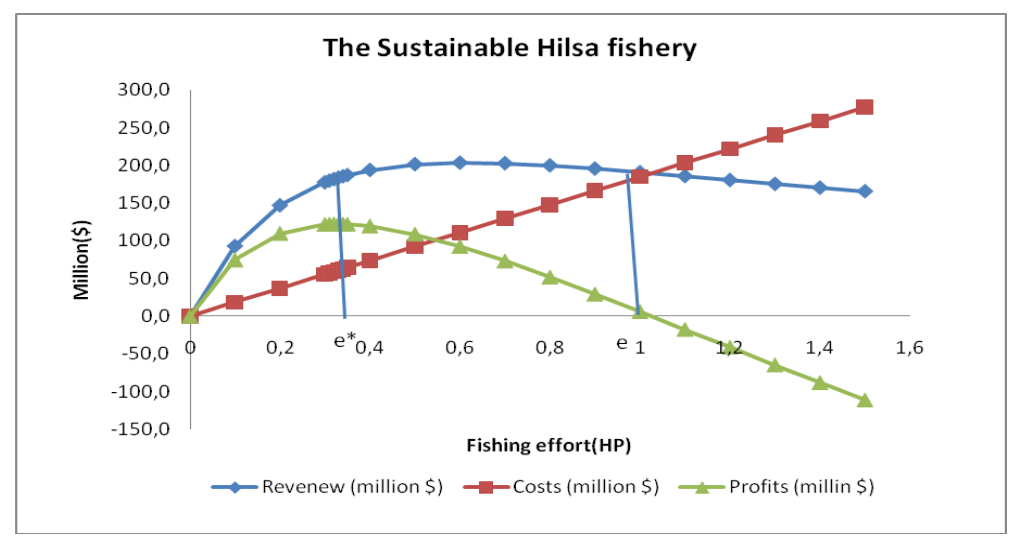

Fig. 5. The sustainable hilsa fishery (per $1 / 2$ year) 
Further comparison of some key statistics for the optimal sustainable fishery with the ones from the current (2005) state of the fishery current one is provided in Table 3.

Table 3. Numerical comparison between the optimum situation and current situation (6mons)

\begin{tabular}{lccccccc}
\hline Hilsa & $\begin{array}{c}\text { Fishing } \\
\text { effort } \\
\text { Fishery }\end{array}$ & $\begin{array}{c}\text { Spawning } \\
\text { stock } \\
(1000 \mathrm{mt})\end{array}$ & $\begin{array}{c}\text { Total hilsa } \\
\text { stock } \\
\text { (age }>6 \\
\text { months) }\end{array}$ & $\begin{array}{c}\text { Total } \\
\text { harvest } \\
(1000 \mathrm{mt})\end{array}$ & $\begin{array}{c}\text { Revenues } \\
\text { (million } \\
\text { US\$) }\end{array}$ & $\begin{array}{c}\text { Costs } \\
\text { (million } \\
\text { US\$) }\end{array}$ & $\begin{array}{c}\text { Profits } \\
\text { (million } \\
\text { US\$) }\end{array}$ \\
\hline $\begin{array}{l}\text { Optimal } \\
\text { fishery }\end{array}$ & 0,33 & 417 & 448 & 95 & 189 & 61 & 129 \\
$\begin{array}{l}\text { Current } \\
\text { fishery }\end{array}$ & 1 & 177 & 202 & 99 & 199 & 185 & 14 \\
\hline
\end{tabular}

Dynamic adjustment path of hilsa fishery: Having identified the optimal sustainable hilsa fishery, we now turn our attention to task of how to move from the current position of the fishery to the optimal sustainable one. The objective of the study is to find economically efficient adjustment paths to the long run optimal level. Seen from a slightly different perspective, this amounts to designing a rebuilding policy for the fishery.

In the dynamic context the appropriate social objective is to maximize the present value of economic benefits from the fishery (Clark and Munro 1975, Hartwick and Oleweiler 1998). This implies choosing a time path for the available fisheries controls, e. g. fishing effort and protection of young cohorts in our case, so that this objective is achieved.

It turns out that the dynamic path which maximizes the present value of economic benefits from the fishery is characterized by a complete moratorium of fishing in the first period followed. This is unlikely to be politically acceptable. More importantly, it may imply substantial social coasts not accounted for our model. Thus, in addition to the dynamic path which maximizes the present value of benefits, we also consider a more moderate path which reduces fishing effort gradually but still reaches the long run optimal level on due course.

Present value of profits maximizing path: Locating present value maximizing paths is an exercise in dynamic optimization. We have solved this optimization problem approximately by numerical search. This essentially consists of comparing the present values of a great number of control paths and picking the highest one. 

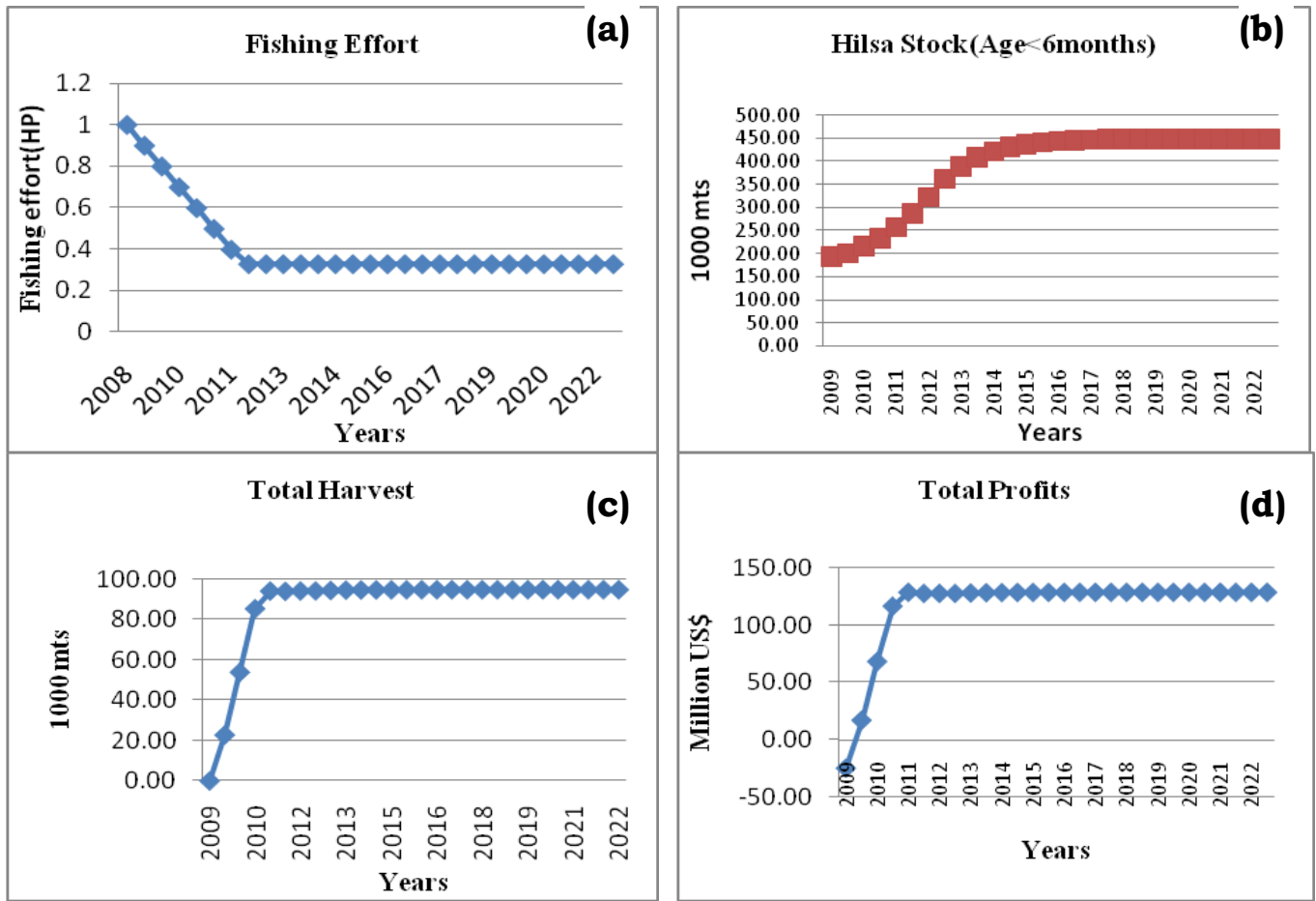

Fig. 6. Profit maximizing path; 6(a) Fishing effort; 6(b) Hilsa biomass/stocks; 6(c) Total harvest; 6(d) Total Profits

We found that the profit maximizing path involved the following main ingredients: (i) fully protecting the youngest cohort from the first period onwards; (ii) reducing fishing effort to zero in the first period and then gradually increasing it to the long run optimal effort level over the following 4 periods or 2 years. The actual fishing effort path is illustrated in Figure 6, panel a. The other key outcomes of this policy, the evolution of the hilsa stock, the level of harvest and annual profits are illustrated in the other panels of the same figure (Figure 6).

As can be seen from Figure 6 the hilsa stock increases more or less monotonically under this policy. The harvest, naturally collapses in the first period and remains low for the next two periods. Then it increases considerable and actually is slightly increased compared to the current harvest before settling down to the long run optimal level. Profits are negative in the first year but then turn positive and have become very substantial already in the third period. The present value of this dynamic path is found to be US\$ 3960 million at a rate of discount of $6 \%$. 

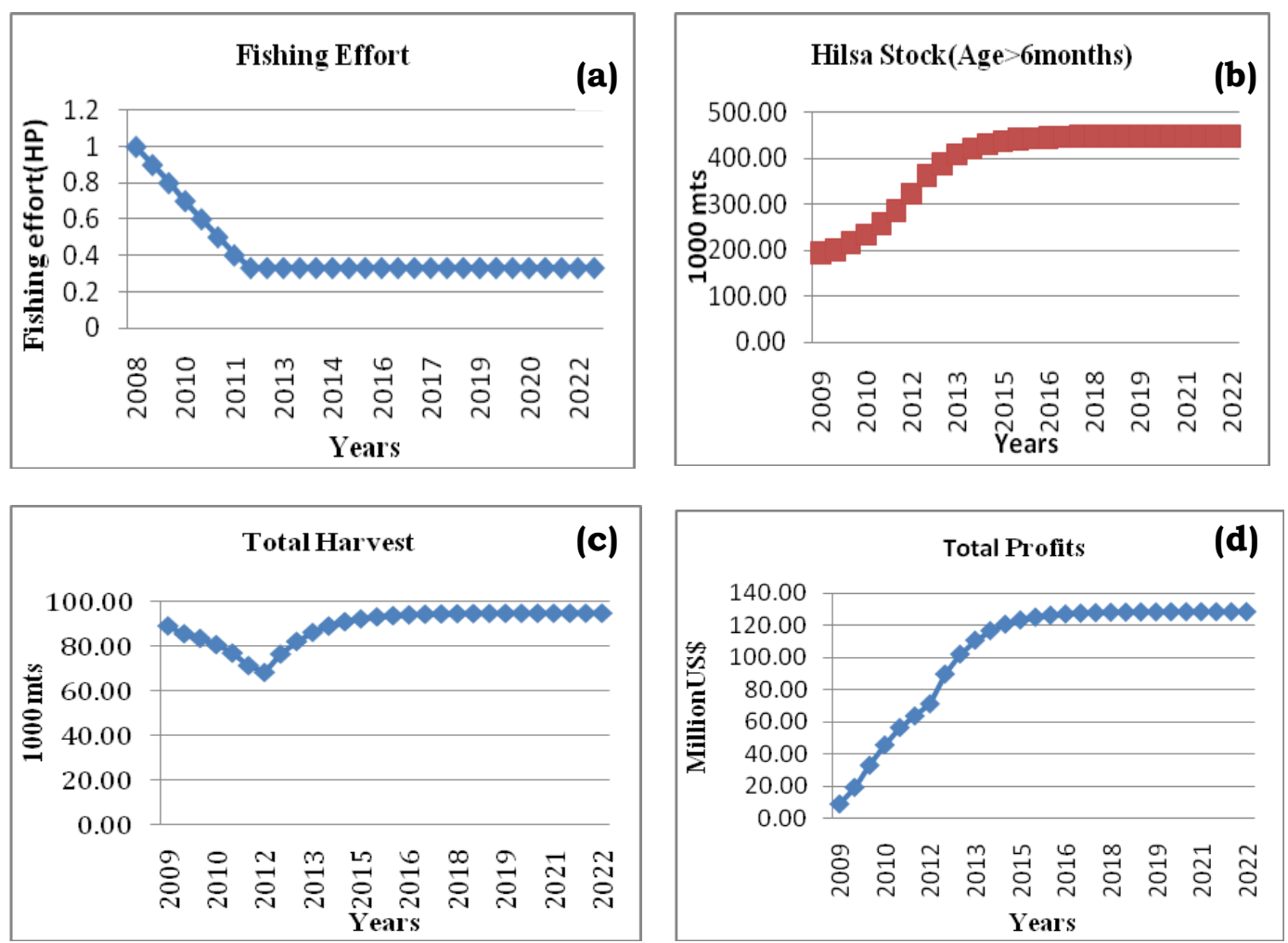

Fig. 7. Moderate path: 7(a) Fishing effort; 7(b) Hilsa stock/biomass; 7(c) Total harvest; 7 (d) Total profits

A moderate path: The profit maximizing path involves drastic cut-backs in fishing effort and hence catches also dropped during the first periods. There may be social costs associated with these drastic changes which are not accounted for in the fisheries model. For this reasons, we also specify a moderate effort reduction path for hilsa fishery. According to this path, fishing effort is gradually reduced from its current down at the 0.33 level over a seven periods (3.5 years). The youngest cohort is still fully protected from the first period onwards. The main outcomes of this moderate policy are illustrated in Fig. 7.

Under this more moderate control path, hilsa biomass takes considerably longer to be built up. However, it increases monotonically toward the long run equilibrium. The harvest contracts slowly during the first phase of the policy reaching a minimum of about 68 thousand mt compared to about 95 thousand met in the base year in period seven (after 3.5 years). Subsequently, the harvest rate increases fast toward the long run equilibrium. Profits from the fishery are never negative and increase slowly for about 16 periods (8 years) when the fishery are close to the long run level. The present value of profits according to this policy is 3650 million US\$. This is about $8 \%$ less than under the present value maximizing policy. 
According to the above results, the hilsa fishery suffers from greatly excessive fishing effort and, consequently, overexploited stocks and much reduced flow of net economic benefits. This is not surprising. The hilsa fishery is essentially an open access, common pool fishery. Moreover, it is a well established mature fishery. Both accepted theory and experience from numerous real fisheries have shown that such fisheries invariably exhibit these features. The only real question in particular cases is the extent of the economic inefficiency and stock overutilization.

The model calculations indicate that the optimal equilibrium fishing effort for hilsa is only about one-third of the current fishing effort. This is equivalent to a reduction in the number of current fishing boats from about 25.000 to 8.400. Moreover, in optimal equilibrium, all jakta fishing ( $1^{\text {st }}$ half year cohort) should be ended. According to the calculations; if jatka is not protected and current fishing effort maintained, the fishery is in a serious danger of a collapse.

At the optimal sustainable equilibrium the calculations suggest that the total stock of hilsa was more than doubled. The spawning stock increased even more. At the same time the harvest rate was about the same, so downstream activities in the hilsa industry, landings, processing, trading, transportation etc. were largely unchanged. Most importantly, however, according to the above, the net economic benefits derived from the hilsa fishery would greatly increase from virtually zero to over US\$ 260 million per year. This annual gain on sustainable basis, can, if properly used, go a long way toward permanently improving the economic and social situation of the fishing communities. It should be noted that these calculations ignored the possible benefits of higher unit prices of hilsa due to larger landing sizes and the benefits from a wider distribution of landings as the stock extended its range.

To move from the current hilsa exploitation level to the long run optimal level takes time. Initially, in order to rebuild the hilsa stock, harvest rates could have to be reduced. Dynamic adjustment paths which maximize the present value of economic benefits over time involve quite drastic reductions in fishing effort and harvests during the first two to three half-years. However, as demonstrated above, it is possible to define more moderate adjustment paths which maintain fairly high catch levels every year while attaining the long run OSY within a reasonable time (i.e. 10 years) and without much loss in the present value of economic benefits (under 10\%). Such paths may well be socially more acceptable.

\section{LITERATURE CITED}

AMIN, S. M., RAHMAN, M. A., HALDAR, G. C., NAHAR, S., DEWAN, S. and MAZID, M.A., 2000. Population Dynamics of Jatka ( Jatka Hilsa) in the Meghna River, Bangladesh. Asian Fisheries Science. 13: 383-389.

ARNASON, R. 2007. Fisheries Management: Basic Principles. In Fisheries and Aquaculture, [Ed. Patrick Safran], in Encyclopedia of Life Support Systems (EOLSS), 
Developed under the auspices of the UNESCO, Eolss Publishers, Oxford ,UK. (2007) [http://www.eolss.net ].

ARNASON. R. 1984. Efficient fisheries: The case of the Icelandic Demarsal fisheries. Ph. D thesis. University of British Colambia.

BEVERTON, R.J.H. and HOLT, S.J. 1957. On the dynamics of exploited fish populations. Fisheries Investigations, Ministry of Agriculture, Fisheries and Food, United Kingdom. Series 2, 19 pp.

CLARK, C.W. and G.R. MUNRO. 1975. The Economics of Fishing and Modern Capital Theory: A Simplified Approach. Journal of Environmental Economics and Management 2(2): 92-106.

DEPARTMENT OF FISHERIES (DoF), 2005-2006. Fish Catch Statistics, various issues. Department of Fisheries, Government of the People's Republic of Bangladesh.

DEPARTMENT OF FISHERIES (DoF), 2010. Annual Report. Department of Fisheries, Government of the People's Republic of Bangladesh.

HALDAR, G.C. 2004a. Ilish Mach Songrokhon abog Unnoun Baboshthapona Bastobaon koushol (In Bengali) (The Implementation of Hilsa Conservation, Development and Management Technique) Department of Fisheries (DoF) Dhaka, Bangladesh.

HALDAR, G.C. 2004b. Present status of the hilsa fishery in Bangladesh. Completion report of the studies conducted under the ARDMCS, GEF component; and FFP. Report No. 38.8, Department of Fisheries, Dhaka, Bangladesh.

HALDAR, G.C., 2002. Hilsa fishery management action plan for Bangladesh. Completion report of the studies conducted under the ARDMCS, GEF component; and FFP. Report No. 38.9, Department of Fisheries, Dhaka, Bangladesh.

HALL, R. and KASEM, M.A. 1994. Chandi boat motorization project in Bhola, Bangladesh and their impacts. BOBP/REP/64.

HAROON, Y, 1998. Hilsa shad: Fish for the teeming millions, new management alternatives needed for the hilsa young. Shad Journal 3: 7 .

HARDIN, G. 1968. The tragedy of the Commons. Science 162: 12, 43-47

HARTWICK, J. M. and OLEWILER, N. D., 1998. The Economics of Natural Resources Use, Second edition. USA: Addison-Wesley Educational Publishers Inc.

GORDON, H. S. 1954. The economic Theory of a Common Property Economy. 62: 24-42.

KHEIH, U., ALAM, K., DASTIDAR, R.., DATTA, U., OUDWATER, N. and WORD, A. 2003, Livelihoods in coastal fishing communities and the marine fish marketing systems of Bangladesh. NRI report NO, 2712, National Resources Institute (NRI), Greenwich University, London.

Le CREN, E.D. 1951. The length-weight relationships and seasonal cycle in gonad weight and condition in perch (Perca fluviatilis). Journal of Anima Ecology. 20(2): 201219.

QUDDUS, M. M. A., M. Shimizu and Y. Nose, 1984. Comparison of age and growth of two types of Hilsa ilisha in Bangladesh waters. Bull. Japan Soc. Sci. Fish. 50: 5157 . 
MIAH, M.S. and M. SHAFI, 1995. Stock assessment and management of Hilsa. (In Bengali). Seminar on sustainable fish and shrimp culture in Bangladesh. Edited by M.A.Mazid. BFRI. Mymensingh: 101-105

RAHMAN, M.J., M.G. MUSTAFA and M.A. RAHMAN.1998. Population dynamics and recruitment

pattern of hilsa, Tenualosa ilisha. Proceedings of BFRI/ACIAR/CSIRO 6: 28-36.

RAHMAN, M.A., S.M. NURUL AMIN, G.C. HALDAR and M.A. MAZID, 2000. Population Dynamicsof Tenualosa ilisha of Bangladesh water. Pakistan Journal of Biological Sciences 3(4):564-567.

RAHMAN, M. 2005. The story of the Hilsa shad. [12 November 2007] $<$ http://asiaarecipe.com/ banchad.html >

RAJA, B.T. A. 1985. A review of the biology and fisheries of hilsa in the upper Bay of Bengal. Marine Fishery Resource Management in the Bay of Bengal. BOBP/WP/37: $66 \mathrm{pp}$.

(Manuscript received on 09 April, 2015l; revised on 11 May 2015) 